\title{
The Taylor Rule and Optimal Monetary Policy
}

\author{
By Michael WOODFORD*
}

John B. Taylor (1993) has proposed that U.S. monetary policy in recent years can be described by an interest-rate feedback rule of the form

$$
\begin{aligned}
i_{t}= & 0.04+1.5\left(\pi_{t}-0.02\right) \\
& +0.5\left(y_{t}-\bar{y}_{t}\right)
\end{aligned}
$$

where $i_{t}$ denotes the Fed's operating target for the federal funds rate, $\pi_{t}$ is the inflation rate (measured by the GDP deflator), $y_{t}$ is the log of real GDP, and $\bar{y}_{t}$ is the $\log$ of potential output (identified empirically with a linear trend). The rule has since been subject to considerable attention, both as an account of actual policy in the United States and elsewhere, and as a prescription for desirable policy. Taylor argues for the rule's normative significance both on the basis of simulations and on the ground that it describes U.S. policy in a period in which monetary policy is widely judged to have been unusually successful (Taylor, 1999), suggesting that the rule is worth adopting as a principle of behavior.

Here I wish to consider to what extent this prescription resembles the sort of policy that economic theory would recommend. I consider the question in the context of a simple, but widely used, optimizing model of the monetary transmission mechanism, which allows one to reach clear conclusions about economic welfare. The model is highly stylized but incorporates important features of more realistic models and allows me to make several points that are of more general validity. Out of concern for the robustness of the conclusions reached, the analysis here addresses only broad, qualitative features of the Taylor rule and attempts to identify

\footnotetext{
* Department of Economics, Princeton University, Princeton, NJ 08544-1021. I thank Jim Bullard, Julio Rotemberg, John Taylor, and John Williams for helpful comments, Argia Sbordone for discussion and for providing the figures, and the NSF for research support.
}

features of a desirable policy rule that are likely to hold under a variety of model specifications.

\section{The Taylor Principle and Determinacy}

A first question about the Taylor rule is whether commitment to an interest-rate rule of this kind, incorporating no target path for any monetary aggregate, can serve to determine an equilibrium price level at all. It is sometimes argued that interest-rate rules as such are undesirable, as they lead to indeterminacy of the rational-expectations equilibrium price level. But this familiar result assumes a rule that specifies an exogenous path for the short-term nominal interest rate; determinacy is instead possible in the case of feedback from an endogenous state variable such as the price level. In fact, many simple optimizing models imply that the Taylor rule incorporates feedback of a sort that suffices to ensure determinacy, owing to the dependence of the funds-rate operating target upon recent inflation and output-gap measures.

Here I consider the question in the context of the "neo-Wicksellian" model derived in Woodford (2000). This reduces to a pair of log-linear relations, an intertemporal "IS" equation of the form

$$
y_{t}=E_{t} y_{t+1}-\sigma\left(i_{t}-E_{t} \pi_{t+1}\right)+g_{t}
$$

and an expectations-augmented " $A S$ " equation of the form

$$
\pi_{t}=\kappa\left(y_{t}-y_{t}^{\mathrm{n}}\right)+\beta E_{t} \pi_{t+1} .
$$

Here $g_{t}$ and $y_{t}^{\mathrm{n}}$ are composite exogenous disturbances, and the coefficients satisfy $\sigma, \kappa>0$, $0<\beta<1$.

Let monetary policy be specified by an interestrate rule of the form

$$
i_{t}=i_{t}^{*}+\phi_{\pi}\left(\pi_{t}-\bar{\pi}\right)+\phi_{y}\left(y_{t}-y_{t}^{\mathrm{n}}-\bar{x}\right),
$$

where $i_{t}^{*}$ is any exogenous stochastic process for the intercept, and $\bar{\pi}$ and $\bar{x}$ are constant "target" 
values for the inflation rate and the output gap, respectively. Then using (4) to eliminate $i_{t}$ in (2), the system in (2) and (3) can be written in the form

$$
E_{t} \mathbf{z}_{t+1}=\mathbf{A} \mathbf{z}_{t}+\mathbf{e}_{t}
$$

where $\mathbf{z}_{t}^{\prime}=\left[\begin{array}{ll}\pi_{t} & y_{t}\end{array}\right]$, and $\mathbf{e}_{t}$ is a vector of exogenous terms. System (5) has a unique stationary solution (assuming stationary disturbance processes) if and only if both eigenvalues of the matrix A lie outside the unit circle. If we restrict attention to policy rules with $\phi_{\pi}, \phi_{y} \geq$ 0 , this condition holds if and only if

$$
\phi_{\pi}+\frac{1-\beta}{\kappa} \phi_{y}>1
$$

The determinacy condition (6) has a simple interpretation. A feedback rule satisfies the Taylor principle if it implies that, in the event of a sustained increase in the inflation rate by $k$ percent, the nominal interest rate will eventually be raised by more than $k$ percent. (Taylor [1999] stresses this as a criterion for sound monetary policy.) In the context of the model sketched above, each percentage point of permanent increase in the inflation rate implies an increase in the long-run average output gap of $(1-\beta) / \kappa$ percent; thus a rule of the form represented by (4) conforms to the Taylor principle if and only if the coefficients $\phi_{\pi}$ and $\phi_{y}$ satisfy (6). In particular, the coefficient values in (1) necessarily satisfy the criterion, regardless of the size of $\beta$ and $\kappa$. Thus the kind of feedback prescribed in the Taylor rule suffices to determine an equilibrium price level. Woodford (2000) shows that the Taylor principle continues to be necessary and sufficient for determinacy when the family of rules is extended to allow for interest-rate inertia of the kind characteristic of estimated Federal Reserve Board reaction functions.

Another argument against interest-rate rules with a venerable history asserts that targeting a nominal interest rate allows for unstable inflation dynamics when inflation expectations extrapolate recent inflation experience. The basic idea, which originates in Knut Wicksell's description of the "cumulative process," is that an increase in expected inflation, for whatever reason, leads to a lower perceived real interest rate, which stimulates demand. This generates higher inflation, increasing expected inflation still further and driving inflation higher in a self-fulfilling spiral. But once again, the classic analysis implicitly assumes an exogenous target path for the nominal interest rate. The sort of feedback from inflation and the output gap called for by the Taylor rule is in fact of the sort needed to damp such an inflationary spiral.

James Bullard and Kaushik Mitra (2000) consider the stability of rational-expectations equilibrium under a form of adaptive learning dynamics in the model sketched above, again in the case of a policy rule of form (4). They find that condition (6) is also necessary and sufficient for "expectational stability" of the equilibrium (i.e., for convergence of the learning dynamics to rational expectations). Thus they confirm the Wicksellian instability result in the case of feedback from inflation or the output gap that is too weak; but this is not a problem in the case of a rule that conforms to the Taylor principle. Taylor's emphasis upon raising interest rates sufficiently vigorously in response to increases in inflation is again justified.

\section{Inflation and Output-Gap Stabilization Goals}

Even granting that the Taylor rule involves feedback of a kind that should tend to exclude instability due purely to self-fulfilling expectations, one must consider whether the equilibrium determined by such a policy is a desirable one. The dependence of the funds-rate target upon the recent behavior of inflation and of the output gap is prescribed in order to damp fluctuations in those variables, and Woodford (2000) shows that in the simple model described above it has this effect. But are inflation and output-gap stabilization in fact sensible proximate goals for monetary policy?

Woodford (1999a) argues that both inflation and output-gap stabilization are sensible goals of monetary policy, as long as the "output gap" is correctly understood. In fact, the paper shows that in the context of the simple optimizing model behind equations (2) and (3), it is possible to motivate a quadratic loss function as a secondorder Taylor-series approximation to the expected utility of the economy's representative household, 
equal to the expected discounted sum of period losses for certain coefficients $\lambda>0$ and $x^{*}>0$ :

$$
L_{t}=\pi_{t}^{2}+\lambda\left(y_{t}-y_{t}^{\mathrm{n}}-x^{*}\right)^{2} .
$$

Here $y_{t}^{\mathrm{n}}$ is the same exogenously varying natural rate of output as in (3). This is defined as the equilibrium level of output that would obtain in the event of perfectly flexible prices; in general, this will not grow with a smooth trend, as a result of real disturbances of many kinds.

There is a simple intuition for the two stabilization objectives in (7). To the degree of approximation discussed in Woodford (1999a), the efficient level of output $y_{t}^{\mathrm{e}}$ (the same for all goods, in the presence of purely aggregate shocks) varies in response to real disturbances in exactly the same proportion as does the flexible-price equilibrium level $y_{t}^{\mathrm{n}}$, the two differ at all times by the constant factor $x^{*}>0$. The average squared deviation of the log output of each good from the efficient level can then be decomposed into the squared deviation of the average $\log$ output $y_{t}$ from the efficient level and the variance of the log output level across individual goods. This latter output dispersion term is in turn proportional to the dispersion of prices across goods due to imperfect synchronization of price changes, which in the case of a particular model of staggered price-setting is proportional to the square of the inflation rate. This last result [and hence the exact form (7)] is somewhat special. But the connection between price dispersion and instability of the general level of prices holds more generally, so that a goal of inflation stabilization may be justified on more general grounds.

We thus find that the stabilization goals implicit in the Taylor rule have a sound theoretical basis, subject to two important qualifications. The first is that Taylor's classic formulation of the rule seeks to stabilize inflation around a target rate of 2 percent per annum. Instead, the welfare-theoretic loss function (7) implies that the target rate of inflation should be zero, as this is the rate that minimizes relative-price distortions associated with imperfect synchronization of price changes. Taking account of additional frictions may modify this conclusion, but in general this will also justify the introduction of additional stabilization goals as well (Woodford, 1999a).
The second qualification is that the "output gap" that one should seek to stabilize is the gap between actual output and the natural rate of output defined above. This contrasts with the assumption made in Taylor's (1993) comparison between the proposed rule and actual U.S. policy, where the output gap is assumed to be measured by output relative to a deterministic trend. In theory, a wide variety of real shocks should affect the growth rate of potential output in the relevant sense; as shown in Woodford (2000), these include technology shocks, changes in attitudes toward labor supply, variations in government purchases, variation in households' impatience to consume, and variation in the productivity of currently available investment opportunities, and there is no reason to assume that all of these factors follow smooth trends. As a result, the output-gap measure that is relevant for welfare may be quite different from simple detrended output.

One source of evidence that this is so comes from a comparison of a detrended output series with the behavior of real unit labor costs. In the model that underlies both (3) and (7), the output gap $y_{t}-y_{t}^{\mathrm{n}}$ appears because the average ratio of marginal supply cost to price is an increasing function of it; this cost/price ratio determines both the incentive to raise prices in (3) and the deadweight losses in (7). A measure of real marginal cost is thus an appropriate proxy for the relevant output gap. But in quarterly U.S. data, variations in real unit labor cost are negatively correlated with detrended real GDP (Fig. 1). Moreover, Argia M. Sbordone (1998) shows that equation (3) gives a very poor account of U.S. inflation when detrended real GDP is used as the gap measure but explains much of the medium-frequency variation when real unit labor costs are used instead (see also Jordi Galí and Mark Gertler, 1999.)

In each panel of Figure 2, a small, unrestricted vector autoregression (VAR) is used to forecast the future evolution of the gap proxy, and then (3) is "solved forward" to obtain a predicted quarterly inflation series. The assumed value of $\beta$ is 0.99 ; in panel (b), the elasticity $\kappa$ is chosen to minimize the meansquare prediction error, while in panel (a) an arbitrary positive value is assumed (as predicted inflation is negatively correlated with actual inflation in any event). The dramatic improve- 


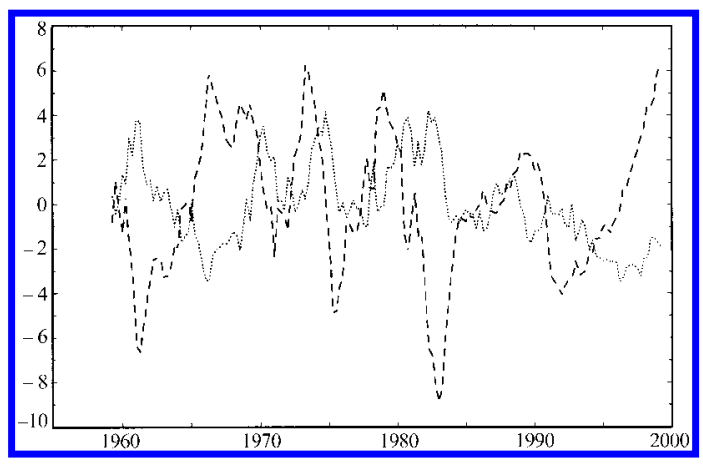

Figure 1. Alternative Measures of the Output Gap

Note: The dashed line shows detrended real GDP, while the dotted line shows real unit labor costs (ULC).

ment in fit in panel (b) suggests that real unit labor cost is a much better measure of the true output gap, at least for purposes of explaining inflation variation. But Figure 1 indicates that the use of such an alternative measure would matter greatly for practical implementation of the Taylor rule.

\section{Optimal Responses to Real Disturbances}

Supposing now that a central bank responds to appropriate measures of the economy's departure from its stabilization goals, I turn to a subtler question. Is the contemporaneous feedback prescribed in (1) sufficient to ensure an optimal response of policy to real disturbances? The answer is that in general, a rule this simple (one that avoids any direct response to other information about the real disturbances, and that incorporates only contemporaneous feedback from the goal variables) must be suboptimal.

As a simple illustration of this, suppose again that all real disturbances affect $y_{t}^{\mathrm{n}}$ and $y_{t}^{\mathrm{e}}$ equally. Then it is optimal to completely stabilize both inflation (at zero) and the output gap (at the level consistent with zero inflation). However, this is not possible with a rule of form (4) where the intercept is a constant, for if in equilibrium inflation and the output gap are both constant, such a rule would prescribe a constant interest rate. Instead, in the optimal equilibrium the interest rate must satisfy $i_{t}=$ $r_{t}^{\mathrm{n}}$, where

$$
r_{t}^{\mathrm{n}}=\sigma^{-1}\left[g_{t}+E_{t}\left(y_{t+1}^{\mathrm{n}}-y_{t}^{\mathrm{n}}\right)\right]
$$

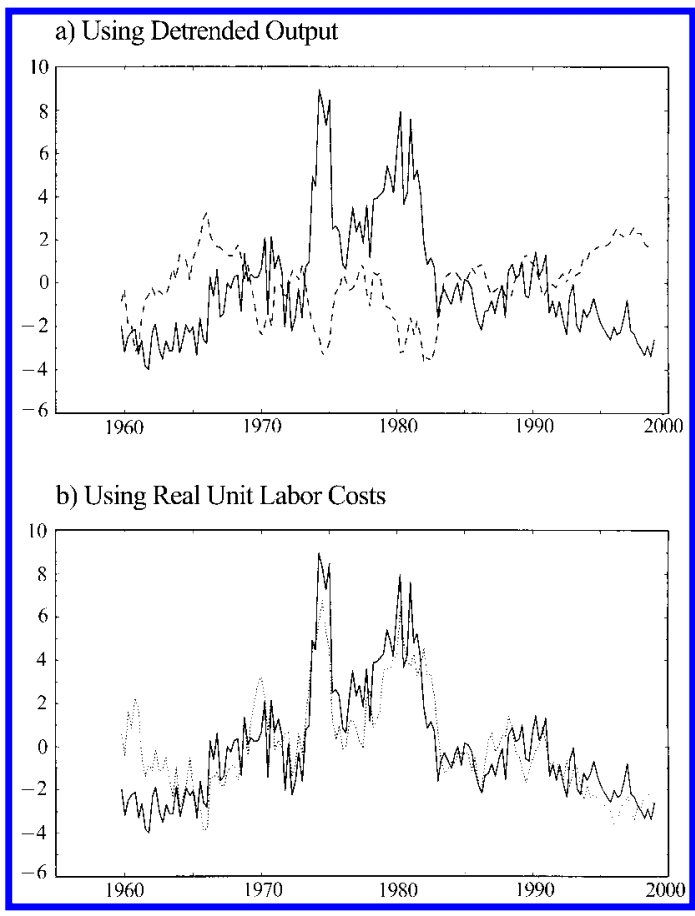

Figure 2. Inflation Predicted Using Alternative GAP MEASURES

Note: The solid lines show actual inflation, while the dashed line (panel a) and dotted line (panel b) show predicted inflation. The assumed value of $\beta$ is 0.99 . In (a), an arbitrary positive value of elasticity $\kappa$ is assumed, while in (b) $\kappa$ is chosen to minimize the mean-square prediction error.

is the Wicksellian natural rate of interest (i.e., the equilibrium real rate under flexible prices). In our simple model, $r_{t}^{\mathrm{n}}$ is an exogenous process (independent of monetary policy), but it should vary in response to a wide range of real disturbances.

A policy rule of form (4) is consistent with the optimal equilibrium, however, if it satisfies two requirements. First, $\phi_{\pi}$ and $\phi_{y}$ must satisfy (6), in order to ensure determinacy. Second, the rule must include a time-varying intercept $i_{t}^{*}=$ $r_{t}^{\mathrm{n}}$, for consistency with a stable inflation rate and output gap. Such a variable intercept is actually in the spirit of Taylor's prescription, which describes the intercept as incorporating "the central bank's estimate of the equilibrium real rate of interest" (Taylor, 1999 p. 325). But for his empirical illustration, Taylor assumes this to be a constant ( 2 percent), while in reality there may be substantial variation in the natural 
rate. Failure to adjust the intercept to track variation in the natural rate of interest will result in fluctuations in inflation and the output gap, just as in Wicksell's analysis (Woodford, 2000).

Of course, in a more realistic analysis, the optimal equilibrium is unlikely to involve complete stabilization of inflation and output. For example, while many real disturbances should affect $y_{t}^{\mathrm{n}}$ and $y_{t}^{\mathrm{e}}$ equally, others may not (Woodford, 1999a; Marc P. Giannoni, 2000), in which case it is no longer possible to fully stabilize both inflation and the welfare-relevant gap $y_{t}-$ $y_{t}^{\mathrm{e}}$. Alternatively, it may be desirable to accept some variability of inflation and the output gap for the sake of less variable nominal interest rates. In these cases, the optimal equilibrium will involve some fluctuations in inflation and the output gap in response to real disturbances; but contemporaneous feedback from the goal variables is still generally insufficient to bring about optimal interest-rate responses, for when the private sector is forward-looking, optimal policy almost always involves a commitment to some later response to current shocks, which then implies that policy must be historydependent at that later date.

In particular, in the model sketched above, it is optimal for the nominal interest rate to be adjusted only gradually in response to new information about the natural rate of interest (Woodford, 1999b; Giannoni, 2000). This is because (2) implies that aggregate demand is as much affected by expected future short real rates of interest as by current short rates. Thus a predictable policy of gradual interest-rate adjustment allows substantial effects on aggregate demand without requiring large swings in shortterm interest rates. The advantages of interestrate inertia in a generalized Taylor rule have also been shown through numerical analysis in the context of more complex econometric models that nonetheless incorporate realistic degrees of forward-looking private-sector behavior (e.g., John C. Williams, 1999).

\section{Conclusions}

The Taylor rule incorporates several features of an optimal monetary policy, from the standpoint of at least one simple class of optimizing models. The response that it prescribes to fluctuations in inflation or the output gap tends to stabilize those variables, and stabilization of both variables is an appropriate goal, at least when the output gap is properly defined. Furthermore, the prescribed response to these variables counteracts dynamics that could otherwise generate instability due to self-fulfilling expectations.

At the same time, the original formulation of the rule may be improved upon. The measure of the output gap suggested in Taylor's (1993) empirical discussion may be quite different from the theoretically correct measure, as the natural rate of output should be affected by a wide variety of real disturbances. The empirical discussion also assumes a constant intercept, but a desirable rule is likely to require that the intercept be adjusted in response to fluctuations in the Wicksellian natural rate of interest, and this too should vary in response to a variety of real disturbances. Finally, the classic formulation assumes that interest rates should be set on the basis of current measures of the target variables alone, but an optimal rule will generally involve a commitment to history-dependent behavior; in particular, more gradual adjustment of the level of interest rates has important advantages. These considerations call for further research to improve measurement of the natural rates of output and of interest, and to analyze the consequences of inertial rules in the context of more detailed models.

\section{REFERENCES}

Bullard, James and Mitra, Kaushik. "Learning about Monetary Policy Rules." Federal Reserve Bank of St. Louis Working Paper No. 200-001B, July 2000.

-Galí, Jordi and Gertler, Mark. "Inflation Dynamics: A Structural Econometric Analysis." Journal of Monetary Economics, June 1999, 44(3), pp. 195-222.

Giannoni, Marc P. "Optimal Interest-Rate Rules in a Forward-Looking Model." Working paper, Federal Reserve Bank of New York, September 2000.

Sbordone, Argia M. "Prices and Unit Labor Costs: A New Test of Price Stickiness." Institute for International Economic Studies (Stockholm University, Sweden) Seminar Paper No. 653, October 1998.

Taylor, John B. "Discretion versus Policy Rules 
in Practice." Carnegie-Rochester Conference Series on Public Policy, December 1993, 39(0), pp. 195-214.

. "A Historical Analysis of Monetary

Policy Rules," in John B. Taylor, ed., Monetary policy rules. Chicago: University of Chicago Press, 1999, pp. 319-41.

Williams, John C. "Simple Rules for Monetary Policy." Federal Reserve Board (Washington, DC) Finance and Economics Discussion Series Paper No. 1999-12, February 1999.
Woodford, Michael. "Inflation Stabilization and Welfare." Working paper, Princeton University, June 1999a.

. "Optimal Monetary Policy Inertia." National Bureau of Economic Research (Cambridge, MA) Working Paper No. 7261, July 1999b.

. "A Neo-Wicksellian Framework for the Analysis of Monetary Policy." Working paper, Princeton University, September 2000. 


\section{This article has been cited by:}

1. Tommy Sveen, Lutz Weinke. 2013. The Taylor principle in a medium-scale macroeconomic model. Journal of Economic Dynamics and Control 37:12, 3034-3043. [CrossRef]

2. Michael M. Hutchison, Rajeswari Sengupta, Nirvikar Singh. 2013. Dove or Hawk? Characterizing monetary policy regime switches in India. Emerging Markets Review 16, 183-202. [CrossRef]

3. Marcelo Sánchez. 2013. Monetary accommodation, imperfect central bank transparency and optimal delegation. Economics Letters 120:3, 392-396. [CrossRef]

4. Kui-Wai Li. 2013. The US monetary performance prior to the 2008 crisis. Applied Economics 45:24, 3450-3461. [CrossRef]

5. Sarah Zubairy. 2013. INTEREST RATE RULES AND EQUILIBRIUM STABILITY UNDER DEEP HABITS. Macroeconomic Dynamics 1-18. [CrossRef]

6. Florin O. Bilbiie, Roland Straub. 2013. Asset Market Participation, Monetary Policy Rules, and the Great Inflation. Review of Economics and Statistics 95:2, 377-392. [CrossRef]

7. Jasmina Arifovic, James Bullard, Olena Kostyshyna. 2013. Social Learning and Monetary Policy Rules*. The Economic Journal 123:567, 38-76. [CrossRef]

8. E. Brancaccio, G. Fontana. 2013. 'Solvency rule' versus 'Taylor rule': an alternative interpretation of the relation between monetary policy and the economic crisis. Cambridge Journal of Economics 37:1, 17-33. [CrossRef]

9. Jan-Christoph Rülke. 2012. Do professional forecasters apply the Phillips curve and Okun's law? Evidence from six Asian-Pacific countries. Japan and the World Economy 24:4, 317-324. [CrossRef]

10. Rodolfo Cermeño, F. Alejandro Villagómez, Javier Orellana Polo. 2012. Monetary policy rules in a small open economy: an application to Mexico. Journal of Applied Economics 15:2, 259-286. [CrossRef]

11. Bluford H. Putnam, Samantha Azzarello. 2012. A Bayesian interpretation of the Federal Reserve's dual mandate and the Taylor Rule. Review of Financial Economics 21:3, 111-119. [CrossRef]

12. Ali K. Malik. 2012. A comparison of equilibrium under alternative monetary policy rules. Applied Economics Letters 19:14, 1391-1399. [CrossRef]

13. Guido Ascari, Lorenza Rossi. 2012. Trend Inflation and Firms Price-Setting: Rotemberg Versus Calvo*. The Economic Journal 122:563, 1115-1141. [CrossRef]

14. Christopher Malikane, Tshepo Mokoka. 2012. Monetary policy credibility: A Phillips curve view. The Quarterly Review of Economics and Finance 52:3, 266-271. [CrossRef]

15. FABRIZIO MATTESINI, LORENZA ROSSI. 2012. Monetary Policy and Automatic Stabilizers: The Role of Progressive Taxation. Journal of Money, Credit and Banking 44:5, 825-862. [CrossRef]

16. Campbell Leith, Ioana Moldovan, Raffaele Rossi. 2012. Optimal monetary policy in a New Keynesian model with habits in consumption. Review of Economic Dynamics 15:3, 416-435. [CrossRef]

17. Barbara Annicchiarico, Nicola Giammarioli, Alessandro Piergallini. 2012. Budgetary policies in a DSGE model with finite horizons. Research in Economics 66:2, 111-130. [CrossRef]

18. C. James Hueng. 2012. Central Bank Behavior and Statutory Independence. Atlantic Economic Journal 40:2, 111-126. [CrossRef]

19. Nikolai Stähler, Carlos Thomas. 2012. FiMod - A DSGE model for fiscal policy simulations. Economic Modelling 29:2, 239-261. [CrossRef]

20. Ivan Petrella, Emiliano Santoro. 2012. Inflation dynamics and real marginal costs: New evidence from U.S. manufacturing industries. Journal of Economic Dynamics and Control . [CrossRef]

21. Stefan Kühn, Joan Muysken. 2011. Why inflation targeting central banks seem to follow a standard Taylor rule. Economics Letters . [CrossRef] 
22. Mahir Binici, Yin-Wong Cheung. 2011. Exchange rate dynamics under alternative optimal interest rate rules. Pacific-Basin Finance Journal 20:1, 122-150. [CrossRef]

23. Ansgar Belke, Niklas Potrafke. 2011. Does government ideology matter in monetary policy? A panel data analysis for OECD countries. Journal of International Money and Finance . [CrossRef]

24. Chengsi Zhang, Yasutomo Murasawa. 2011. Output gap measurement and the New Keynesian Phillips curve for China. Economic Modelling 28:6, 2462-2468. [CrossRef]

25. Edoardo Gaffeo, Giulia Canzian. 2011. The psychology of inflation, monetary policy and macroeconomic instability. The Journal of Socio-Economics 40:5, 660-670. [CrossRef]

26. Dandan Liu. 2011. Learning and Estimation of the New Keynesian Phillips Curve Models. Southern Economic Journal 78:2, 382-396. [CrossRef]

27. JOHN DUFFY, WEI XIAO. 2011. Investment and Monetary Policy: Learning and Determinacy of Equilibrium. Journal of Money, Credit and Banking 43:5, 959-992. [CrossRef]

28. Tara M. Sinclair, Edward N. Gamber, Herman Stekler, Elizabeth Reid. 2011. Jointly evaluating the Federal Reserve's forecasts of GDP growth and inflation. International Journal of Forecasting . [CrossRef]

29. Damjan Pfajfar, Emiliano Santoro. 2011. Determinacy, stock market dynamics and monetary policy inertia. Economics Letters 112:1, 7-10. [CrossRef]

30. José R. Sánchez-Fung. 2011. Estimating monetary policy reaction functions for emerging market economies: The case of Brazil. Economic Modelling 28:4, 1730-1738. [CrossRef]

31. Cristian Huse. 2011. Term structure modelling with observable state variables. Journal of Banking \& Finance . [CrossRef]

32. Kevin Lee, Kalvinder K. Shields. 2011. Decision-making in hard times: What is a recession, why do we care and how do we know when we are in one?. The North American Journal of Economics and Finance 22:1, 43-60. [CrossRef]

33. CINZIA ALCIDI, ALESSANDRO FLAMINI, ANDREA FRACASSO. 2011. Policy Regime Changes, Judgment and Taylor rules in the Greenspan Era. Economica 78:309, 89-107. [CrossRef]

34. Riccardo Cristadoro, Giovanni Veronese. 2011. Monetary policy in India: is something amiss?. Indian Growth and Development Review 4:2, 166-190. [CrossRef]

35. Giovanni Di Bartolomeo, Marco Manzo. 2010. FISCAL POLICY UNDER BALANCED BUDGET AND INDETERMINACY: A NEW KEYNESIAN PERSPECTIVE. Scottish Journal of Political Economy 57:4, 455-472. [CrossRef]

36. Tatiana Damjanovic, Charles Nolan. 2010. Relative Price Distortions and Inflation Persistence*. The Economic Journal 120:547, 1080-1099. [CrossRef]

37. Bill Dupor, Tomiyuki Kitamura, Takayuki Tsuruga. 2010. Integrating Sticky Prices and Sticky Information. Review of Economics and Statistics 92:3, 657-669. [CrossRef]

38. Philip Arestis, Alexander Mihailov. 2010. CLASSIFYING MONETARY ECONOMICS: FIELDS AND METHODS FROM PAST TO FUTURE. Journal of Economic Surveys no-no. [CrossRef]

39. Tara Sinclair, H. O. Stekler, L. Kitzinger. 2010. Directional forecasts of GDP and inflation: a joint evaluation with an application to Federal Reserve predictions. Applied Economics 42:18, 2289-2297. [CrossRef]

40. Hilde C. Bjørnland, Kai Leitemo, Junior Maih. 2010. Estimating the natural rates in a simple New Keynesian framework. Empirical Economics . [CrossRef]

41. Dandan Liu, Dennis W. Jansen. 2010. Does a factor Phillips curve help? An evaluation of the predictive power for U.S. inflation. Empirical Economics . [CrossRef] 
42. K.P.V. O'Sullivan, Tom Kennedy. 2010. What caused the Irish banking crisis?. Journal of Financial Regulation and Compliance 18:3, 224-242. [CrossRef]

43. John B. Taylor, John C. WilliamsSimple and Robust Rules for Monetary Policy 3, 829-859. [CrossRef]

44. Josephine M. Smith, John B. Taylor. 2009. The term structure of policy rules. Journal of Monetary Economics 56:7, 907-917. [CrossRef]

45. ICHIRO MUTO. 2009. ESTIMATING A NEW KEYNESIAN PHILLIPS CURVE WITH A CORRECTED MEASURE OF REAL MARGINAL COST: EVIDENCE IN JAPAN. Economic Inquiry 47:4, 667-684. [CrossRef]

46. PETER TILLMANN. 2009. Optimal Monetary Policy with an Uncertain Cost Channel. Journal of Money, Credit and Banking 41:5, 885-906. [CrossRef]

47. J. Morgan. 2009. The limits of central bank policy: economic crisis and the challenge of effective solutions. Cambridge Journal of Economics 33:4, 581-608. [CrossRef]

48. Chengsi Zhang, Denise R. Osborn, Dong Heon Kim. 2009. Observed Inflation Forecasts and the New Keynesian Phillips Curve. Oxford Bulletin of Economics and Statistics 71:3, 375-398. [CrossRef]

49. Carlo Rosa. 2009. Forecasting the Direction of Policy Rate Changes: The Importance of ECB Words. Economic Notes 38:1-2, 39-66. [CrossRef]

50. GISLE JAMES NATVIK. 2009. Government Spending and the Taylor Principle. Journal of Money, Credit and Banking 41:1, 57-77. [CrossRef]

51. J BULLARD, A SINGH. 2008. Worldwide macroeconomic stability and monetary policy rules\#. Journal of Monetary Economics 55, S34-S47. [CrossRef]

52. T MOLODTSOVA, A NIKOLSKORZHEVSKYY, D PAPELL. 2008. Taylor rules with real-time data: A tale of two countries and one exchange rate\#. Journal of Monetary Economics 55, S63-S79. [CrossRef]

53. Janko Gorter, Jan Jacobs, Jakob De Haan. 2008. Taylor Rules for the ECB using Expectations Data*. Scandinavian Journal of Economics 110:3, 473-488. [CrossRef]

54. Juan Paez-Farrell. 2008. Assessing sticky price models using the Burns and Mitchell approach. Applied Economics 40:11, 1387-1397. [CrossRef]

55. Silvia Sgherri. 2008. Explicit and implicit targets in open economies. Applied Economics 40:8, 969-980. [CrossRef]

56. Keshab Bhattarai. 2008. An empirical study of interest rate determination rules. Applied Financial Economics 18:4, 327-343. [CrossRef]

57. WEI XIAO. 2008. INCREASING RETURNS AND THE DESIGN OF INTEREST RATE RULES. Macroeconomic Dynamics 12:01. . [CrossRef]

58. Jordi Galsí, Mark Gertler. 2007. Macroeconomic Modeling for Monetary Policy Evaluation. Journal of Economic Perspectives 21:4, 25-45. [Abstract] [View PDF article] [PDF with links]

59. Ansgar Belke, Thorsten Polleit. 2007. How the ECB and the US Fed set interest rates. Applied Economics 39:17, 2197-2209. [CrossRef]

60. Giovanni Di Bartolomeo, Lorenza Rossi. 2007. Effectiveness of monetary policy and limited asset market participation: Neoclassical versus Keynesian effects. International Journal of Economic Theory 3:3, 213-218. [CrossRef]

61. Stephan Sauer, Jan-Egbert Sturm. 2007. Using Taylor Rules to Understand European Central Bank Monetary Policy. German Economic Review 8:3, 375-398. [CrossRef]

62. JAMES BULLARD, KAUSHIK MITRA. 2007. Determinacy, Learnability, and Monetary Policy Inertia. Journal of Money, Credit and Banking 39:5, 1177-1212. [CrossRef] 
63. Mark Setterfield. 2007. Is There a Stabilizing Role for Fiscal Policy in the New Consensus?. Review of Political Economy 19:3, 405-418. [CrossRef]

64. Claude Gnos, Louis-Philippe Rochon. 2007. The New Consensus and Post-Keynesian Interest Rate Policy. Review of Political Economy 19:3, 369-386. [CrossRef]

65. S EUSEPI. 2007. Learnability and monetary policy: A global perspective. Journal of Monetary Economics 54:4, 1115-1131. [CrossRef]

66. Barbara Annicchiarico, Alessandro Piergallini. 2007. Monetary Rules and Deficit Shocks. Spanish Economic Review 9:1, 39-57. [CrossRef]

67. EFREM CASTELNUOVO. 2007. TAYLOR RULES AND INTEREST RATE SMOOTHING IN THE EURO AREA. The Manchester School 75:1, 1-16. [CrossRef]

68. M BRUCKNER, A SCHABERT. 2006. Can money matter for interest rate policy?\#. Journal of Economic Dynamics and Control 30:12, 2823-2857. [CrossRef]

69. Ludger Linnemann, Andreas Schabert. 2006. Monetary Policy and the Taylor Principle in Open Economies. International Finance 9:3, 343-367. [CrossRef]

70. Alessandro Piergallini. 2006. Fiscal Deficits, Taylor Rules, and Price Dynamics. Atlantic Economic Journal 34:4, 395-403. [CrossRef]

71. Alexandros Kontonikas, Alberto Montagnoli. 2006. OPTIMAL MONETARY POLICY AND ASSET PRICE MISALIGNMENTS. Scottish Journal of Political Economy 53:5, 636-654. [CrossRef]

72. Nicoletta Batini. 2006. Euro area inflation persistence. Empirical Economics 31:4, 977-1002. [CrossRef]

73. Jean Boivin, Marc P Giannoni. 2006. Has Monetary Policy Become More Effective?. Review of Economics and Statistics 88:3, 445-462. [CrossRef]

74. Kai Leitemo. 2006. Open-Economy Inflation-Forecast Targeting. German Economic Review 7:1, 35-64. [CrossRef]

75. Pierre L. Siklos, Mark E. WoharEstimating Taylor-Type Rules: An Unbalanced Regression? 20, 239-276. [CrossRef]

76. Arturo Estrella. 2005. Why Does the Yield Curve Predict Output and Inflation?. The Economic Journal 115:505, 722-744. [CrossRef]

77. Giorgio E. Primiceri. 2005. Time Varying Structural Vector Autoregressions and Monetary Policy. Review of Economic Studies 72:3, 821-852. [CrossRef]

78. W CHOI. 2004. Liability dollarization and the bank balance sheet channel*1. Journal of International Economics 64:2, 247-275. [CrossRef]

79. Bas van Aarle, Harry Garretsen, Florence Huart. 2004. Monetary and Fiscal Policy Rules in the EMU. German Economic Review 5:4, 407-434. [CrossRef]

80. Amit Kara, Edward Nelson. 2004. International Evidence on the Stability of the Optimizing IS Equation*. Oxford Bulletin of Economics and Statistics 66:s1, 687-712. [CrossRef]

81. Ludger Linnemann. 2004. Tax Base and Crowding-in Effects of Balanced Budget Fiscal Policy. Scandinavian Journal of Economics 106:2, 273-297. [CrossRef]

82. Ralf Fendel. 2004. Perspektiven und Grenzen der Verwendung geldpolitischer Regeln. Perspektiven der Wirtschaftspolitik 5:2, 169-192. [CrossRef]

83. Andreas Schabert. 2004. Interactions of monetary and fiscal policy via open market operations*. The Economic Journal 114:494, C186-C206. [CrossRef]

84. Lars E. O. Svensson. 2003. What Is Wrong with Taylor Rules? Using Judgment in Monetary Policy through Targeting Rules. Journal of Economic Literature 41:2, 426-477. [Abstract] [View PDF article] [PDF with links] 
85. J Bullard. 2002. Learning about monetary policy rules. Journal of Monetary Economics 49:6, 1105-1129. [CrossRef] 